\title{
Ciudad y Territorial Virtual. 2004-2019, Barcelona 15 años después
}

Rolando Biere Arenas ${ }^{1}$

Recibido: 03-09-2020 | en su versión final: 22-02-2021

Resumen

Este artículo realiza una introducción a la sección especial, que presenta una selección de ponencias destacadas de la XIII Edición del Congreso internacional Ciudad y Territorio Virtual (CTV), realizada en Barcelona en octubre 2019. Para ello se desarrolla una breve presentación del Congreso internacional Ciudad y Territorio Virtual (CTV), organizado desde el Centro de Política de Suelo y Valoraciones (CPSV), iniciado en junio de 2004 (Barcelona) planteado como lugar de encuentro para presentar desarrollos en modelos virtuales y herramientas de representación del entorno construido, centrado en tres bloques; Ciudades Virtuales en el Mundo, Territorio Virtual y Cartografía 3D y Representación Virtual del Patrimonio. Asimismo, se presenta la evolución de sus contenidos (durante sus ediciones alternadas entre Europa y América latina) que mostró una primera gran inflexión en su cuarta edición de 2007, en Guadalajara (México), en la que en base a su llamada a "Repensar la Ciudad" se integraron temas de relevancia social, sin perder de vista las TIC, como herramientas de análisis. Este enfoque es que ha ido avanzando hasta su última edición de 2019, quince años después de su comienzo, nuevamente en Barcelona, cuyo llamado fue "Retos y paradigmas de la ciudad contemporánea." Finalmente se realiza una breve presentación de los trabajos que componen la sección, derivados de las sesiones temáticas que se realizaron durante el congreso.

Palabras clave: congreso internacional; sistemas territoriales y urbanos; TIC aplicadas; aspectos sociales

Citación

Biere Arenas, R. (2021). Ciudad y Territorial Virtual. 2004-2019, Barcelona 15 años después. ACE: Architecture, City and Environment, 15(45), 10380. DOI:

http://dx.doi.org/10.5821/ace.15.45.10380

\section{Virtual City, and Territory. 2004-2019, Barcelona 15 Years After}

Abstract

\begin{abstract}
This article introduces the special section, which presents a selection of outstanding papers from the XIII Edition of the International Conference Virtual City and Territory (CTV), held in Barcelona in September of 2019. In this way, is made a brief presentation of the International Conference Virtual City and Territory (CTV), organized by the Center for Land Policy and Valuations (CPSV), started in June of 2004 (Barcelona), proposed as a meeting place to present developments in virtual models and representation tools of the built environment, centered on three blocks; Virtual Cities in the World, Virtual Territory and 3D Cartography and Virtual Representation of Heritage. Likewise, the evolution of its contents is presented (during its alternate editions between Europe and Latin America) which showed a first great inflection in its fourth edition of 2007, in Guadalajara (Mexico), in which, based on its call to "Rethink the City" topics of social relevance were introduced, without losing sight of ICT, as analysis tools. This approach is that it has been advancing until its last edition of 2019, fifteen years after its beginning, again in Barcelona, whose call was "Challenges and paradigms of the contemporary city." Finally, there is a brief presentation of the works that compose the section, derived from the thematic sessions that were held during the conference.
\end{abstract}

Keywords: International conference; regional and urban systems; applied ICT; social aspects

${ }^{1}$ Arquitecto, M.Sc. Investigador del Centro de Política de Suelo y Valoraciones, CPSV y Profesor asociado departamento de Tecnología de la Arquitectura, TA-UPC. (ORCID: 0000-0003-1872-7104; WoS ResearcherID: 1-5766-2015; Scopus Author ID 57191882461). Correo de contacto: rolando.biere@upc.edu

ACE, 15 (4.5) CC BY-ND 3.0 ES | UPC Barcelona, España | Ciudad y Territorial Virtual. 2004-2019, Barcelona 15 años después. DOI: http://dx.doi.org/10.5821/ace.15.45.10380 